\title{
Effect of Metallic, Nonmetallic, Water Cooled and Cryogenic Chills on Pearlite Content (PC), Eutectic Cell Count (ECC) and Grain Size (GS) of Hypo Eutectic Nickel Alloyed Cast Iron
}

\author{
Joel Hemanth \\ Mechanical Engineering, H.M.S. Institute of Technology, Tumkur, India \\ Email:joelhemanth@hotmail.com
}

How to cite this paper: Hemanth, J. (2017) Effect of Metallic, Nonmetallic, Water Cooled and Cryogenic Chills on Pearlite Content (PC), Eutectic Cell Count (ECC) and Grain Size (GS) of Hypo Eutectic Nickel Alloyed Cast Iron. Modeling and Numerical Simulation of Material Science, 7, 1-18.

https://doi.org/10.4236/mnsms.2017.71001

Received: June 17, 2016

Accepted: February 25, 2017

Published: February 28, 2017

Copyright $\odot 2017$ by author and Scientific Research Publishing Inc. This work is licensed under the Creative Commons Attribution International License (CC BY 4.0).

http://creativecommons.org/licenses/by/4.0/

\begin{abstract}
This paper presents the results obtained, deductions made from solidification behaviour and a series of micro structural studies such as pearlite content, eutectic cell count and grain size of hypoeutectic gray cast iron which was sand cast $\left(\mathrm{CO}_{2}\right.$ moulding) using metallic, nonmetallic, water cooled and subzero (cryogenic) end chills. Hypo-eutectic cast irons containing C 3.42, Si 2.4 and Ni 1.5 with impurity contents (S, P, Mn etc.) were solidified unidirectionally in an American Foundrymen Society (AFS) standard mould, the end of which was provided with different end chills to study the effect of chilling during solidification. The melts were inoculated with $0.3 \% \mathrm{Fe}-\mathrm{Si}$ to promote graphitization. It was observed that the transition from one structure to another is more gradual than normally obtained in the structure of cast irons solidified multi-directionally in a sand mould at room temperature. Austenite dendrite interactions were shown to be a major factor in determining the microstructure, in which the higher dendrite reaction leads to changes in DAS, ECC and GS. It is observed that, the number of eutectic cells is an index of graphite nucleation and the effect of these on structure, since the eutectic cells are developed on the graphite nuclei during solidification.
\end{abstract}

\section{Keywords}

Cast Iron, Chill, Solidification, Pearlite, Eutectic and Grain Size

\section{Introduction}

\subsection{Chilled Cast Iron}

The ability of the chill to extract heat from the molten metal during solidification of the casting is dependent on the size of the chill and thermo-physical 
properties of the chill material. In other words, the capacity of the chill to absorb heat from the casting is taken as a measure of its efficiency. The volumetric heat capacity of the chill, which takes into account the volume, specific heat, and density of the chill material, has been identified as an important factor in the evaluation of the efficiency of the chill [1] [2] [3] [4] [5]. It can be seen that an increase in any one of the factors, $V, C p$ or $\rho$ increases the value of volumetric heat capacity (VHC), thus enhancing the heat transfer. Use of chills in stir casting was made in order to promote directional solidification and to obtain defect free castings. It provides solidification control by establishing steep temperature gradient in the casting during solidification. It extracts heat at chill/composite interface at a faster rate than the sand and thereby establishes directional solidification [6]. Chills are extensively used in sand moulds by a number of researchers for obtaining sound castings. The primary and most important factor to consider in casting is solidification shrinkage because it contributes significantly to the problems encountered during the feeding of castings [7]. This problem is overcome by judicious placement of chill in the mould [8]. Extensive work using embedded chills in various composite systems has been carried out by Joel Hemanth [9] [10] [11]. Earlier to this, chills were used only in the investigations of aluminium alloys solidification and study of the effect of air gap formation during solidification.

Chilled cast iron belongs to a group of metals possessing high strength, hardness, toughness and high wear resistance. For a metallurgist, there is sufficient information available on the solidification mode and cell size of ordinary cast iron in sand moulds. However, there is a serious lack of information on the mode of solidification of chilled cast iron and its effect on cell size, grain size, microstructure and the effects of these on mechanical properties. This prompted to embark upon a series of experiments to study the relationship among these parameters in the case of metallic, nonmetallic, water-cooled and liquid-nitrogen-cooled chilled cast irons. The reason behind the selection of this series of chilled cast iron is that a wide range of microstructures can be obtained with different cell sizes, dendrite arm spacing and grain size.

\subsection{Inoculation of Cast Iron}

Inoculation technique has been used for many years to improve the properties of cast iron and it is generally agreed that inoculation may affect the nucleation of the eutectic during solidification as late addition increase the number of effective nuclei [12]. Inoculation mainly changes the chilling tendency as well as the size of the eutectic cells [12]. Changes in the graphite flake size owing to inoculation were relatively small and the shape of the graphite varied only slightly with the size of the eutectic cells, as could be expected from different rate of growth [13]. In pure alloys, the graphite flakes were frequently branched in a normally ferritic matrix and the inoculation led in no case to coarse type-A graphite [14].

\subsection{Effect of Cooling Rate (Chilling) on Solidification}

When cast iron containing a certain amount of carbon is cooled slowly from the 
melt, large flake graphite appears. When cooling is more rapid, the graphite structure will be fine and under cooled graphite or white cast iron may be present depending on the cooling rate [15]. The structure of the graphite is not only influenced by the cooling rate but also by the carbon content [16]. The specimens chilled at the start of reaction had so many primary dendrites of austenite that the eutectic reaction was restricted. A mushy type of graphite which is present apparently reverts to D-type during solidification if cooling is fast. When cooling is slow, the mushy graphite will be converted into flake graphite even at the beginning of the eutectic reaction [17]. Researchers have also showed that, addition of small amount of Si to pure iron containing 3\% C changed the graphite from a mushy type to flake form. This may be attributed to the fact that addition of $\mathrm{Si}$ raised the carbon equivalent, thus increasing the amount of primary austenite dendrites [18]. Therefore, cast iron containing appreciable amount of Si leads the ledeburite to decompose to graphite during solidification particularly when iron is forcibly solidified to white cast iron by a physical chilling action [19]. Increase in silicon content in cast irons to a point beyond what is needed for ferritic matrix also increases hardness and strength due to solid solution strengthening [20].

In general, the cooling rate during casting is largely governed by the design and thermal nature of the casting procedure, one significant factor being the mould material [21]. Metal moulds generally offer higher chilling action on the solidifying mass due to their heat diffusivity [22]. Therefore, the influence of higher cooling rate is normally responsible for the superior properties of chilled castings [23]. The influence of very high cooling rates in producing fine structures offers the possibility of future development of cast irons possessing high strength, high hardness and fracture toughness [24]. The under-cooling of a melt to a lower temperature increases the number of effective nuclei for solidification relative to the growth rate, the latter being restricted by the rate at which the latent heat of crystallization can be dissipated. Conversely, slow cooling favours the growth from a few solidification nuclei and produces coarse grain structures [25]. The refining effect of enhanced cooling rate applies both to the primary grain size and to the substructure, although in the latter case, the effect is on the growth process rather than on nucleation. Thus, there is a marked effect upon dendritic grain size, cell size and microstructure over a wide range of cooling rates and, consequently on the mechanical properties [26]. Effect of chills on the solidification characteristics of cast iron have been studied by Bishop and his co-workers [27]. J. T. Berry and his associates have shown the importance of solidification time of various castings [28] [29] [30] [31].

\subsection{Grain Size (GS)}

The influence of cooling rate on properties is profound because of its influence on microstructure especially the grain size. Rapid cooling causes fine grain structure and hence increase in hardness and tensile strength. Past research [32] showed that fast cooling of cast iron contained fine pearlite containing large 
amount of cementite. Conversely, slow cooling in heavier sections leads to progressive coarsening grain structure which yields in lamellar pearlite containing large ferrite particles. Thus when related to grain size heat transfer during solidification, inoculation and chilling are considered far more important than chemical specifications. However, certain combinations of carbon and Si and other elements are used more commonly than others. Finally composition, cooling rate, graphitization process, structure and properties developed in the casting are so intimately related that all these factors must be considered when a certain end point is desired in the casting.

\subsection{Eutectic Cell Count (ECC)}

The eutectic graphite nucleation, eutectic cell number and graphite morphologies depend on the composition, cooling rate and increase in the degree of under cooling [33]. The thermal and microscopic observations obtained lend themselves to interpretation in terms of current nucleation and growth concepts contained within the solidification theory of alloys. During non-equilibrium solidification (using chills) of cast iron, three nucleating events are possible: those of the primary austenite, the eutectic graphite and the eutectic ledeburite [34]. Past research has revealed that eutectic graphite has good machinability, high strength, high hardness but has low impact resistance. Nickel in the present investigation is intentionally added as potent alloying element in view of its tremendous potential as grain refiner that improves machinability of hypoeutectic cast iron [35].

\subsection{Relevance of the Research}

- Chilled cast iron belongs to a group of metals possessing very good mechanical properties.

- For a foundrymen, there is sufficient information available on the solidification and microstructure of cast iron, cast in sand moulds. However, there is a serious lack of information on the effect of solidification of cast iron, cast using different chills on pearlite content, eutectic cells and grain size.

- This prompted to embark upon a series of experiments to study the relationship between these parameters in the case of cast irons, cast using different chills.

Hence, the present research work has the following purposes:

1) To obtain experimental data for pearlite content, eutectic cells, grain size and resulting microstructure for various cooling rates

2) To analyze the data in the light of the solidification process, and

3) To correlate micro-constituents such as pearlite, carbide, ferrite volume fractions with eutectic cell size and grain size.

\section{Experimental Procedure}

\subsection{Fabrication of the Material}

Cast iron alloy of composition shown in Table 1 and cast at four different cool- 
ing rates were produced by casting at $1440^{\circ} \mathrm{C}$ in the form of ingots. They shall henceforth be designated by specimen A (liquid-nitrogen-cooled with copper chill), specimen B (water-cooled with copper chill), specimen C (metallic chilled, copper), specimen D (non metallic chilled, graphite) and specimen $\mathrm{E}$ (sand cast without any chill). Apart from the usual alloying elements like Si and ferrosilicon (inoculant), $\mathrm{Ni}$ was added to improve machinability as well as to act as a grain refiner.

\subsection{Casting and Testing Procedure}

Figure 1 shows a schematic diagram of the mould (AFS standard) used for producing the various ingots cast with various types of chills. To make the mould for casting, a teak wood pattern of size $225^{\star} 150^{\star} 25 \mathrm{~mm}$ was employed with standard pattern allowances. The moulds were prepared using silica sand with liquid sodium silicate as the binder. Moulds thus prepared were dried in a $\mathrm{CO}_{2}$ gas chamber at room temperature. The molten alloys were cast in the mould and were cooled from one end by the chill. In the case of water-cooled chilling and liquid-nitrogen-cooled chilling, arrangements were made in the copper chill to circulate water $\left(\right.$ at $20^{\circ} \mathrm{C}$ ) and liquid nitrogen $\left(\right.$ at $-90^{\circ} \mathrm{C}$ ) respectively. Circulation of water and liquid nitrogen was continued till the end of pouring. In all the above cases, chill dimension was $25 \mathrm{~mm}$ in thickness, $35 \mathrm{~mm}$ in breadth and 170 $\mathrm{mm}$ in length.

Table 1. Composition of cast iron tested (Carbon Equivalent $\mathrm{CE}=4.22$ ).

\begin{tabular}{ccccccccc}
\hline Element & $\mathrm{C}$ & $\mathrm{Si}$ & $\mathrm{Mn}$ & $\mathrm{S}$ & $\mathrm{P}$ & $\mathrm{Ni}$ & $\mathrm{Fe}$ \\
\hline \% composition & 3.42 & 2.4 & 0.41 & 0.04 & 0.08 & 1.5 & Balance
\end{tabular}

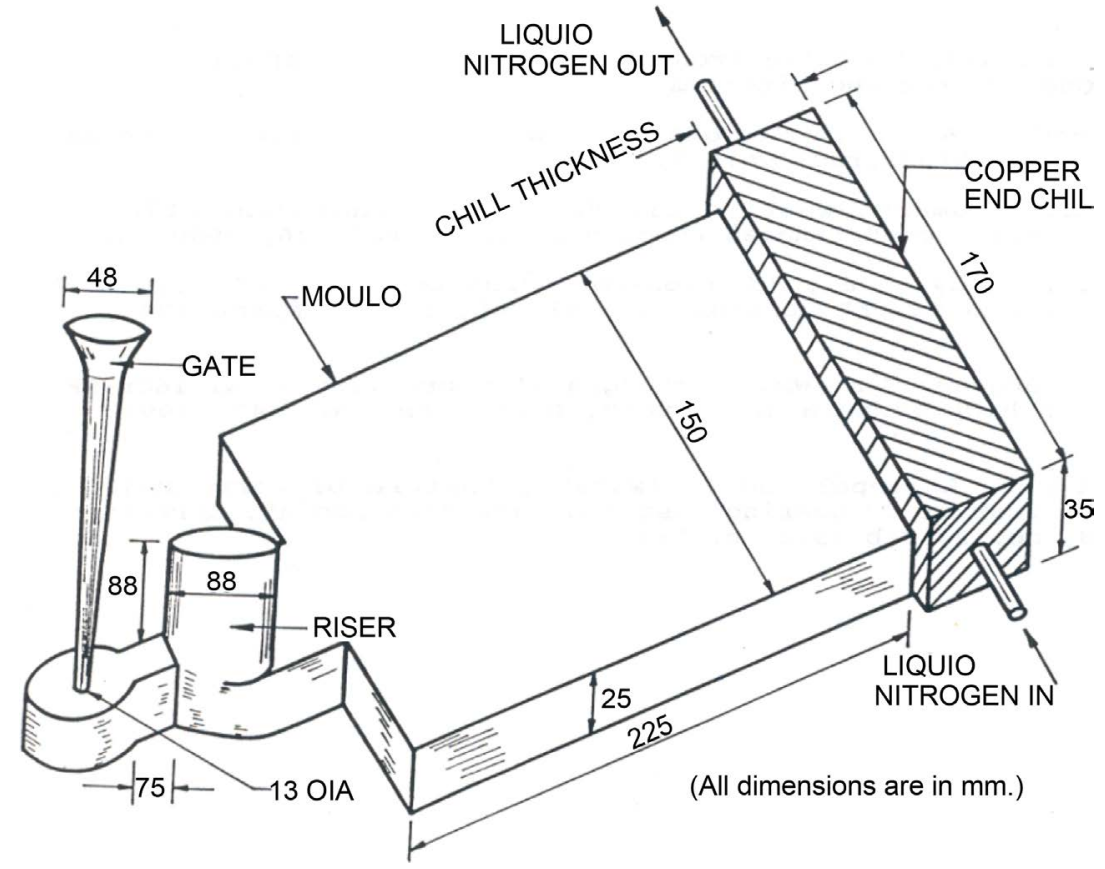

Figure 1. Experimental setup for chill casting. 
Microscopic examination was conducted on all the specimens (chill end to riser end) to determine cell size, grain size, DAS and microstructure using Neophot-21 metallurgical microscope. For this, various etchants were tried but $2 \%$ Nital proved to be the best and was therefore used. Austenite grain size measurements were done on polished specimens using ASTM index method, (direct measurement using standard ASTM mesh on the microscope). Eutectic cell count measurements were carried out on polished specimens at low magnification (50X) using Stead's reagent as the etchant.

Alloy designation: Alloy A-Sub zero copper chilled cast iron Alloy B-Water cool copper chilled cast iron Alloy C-Copper chilled (Metallic) cast iron Alloy D-Graphite chilled (Non metallic) cast iron and Alloy E-Sand cast (Without chill) cast iron.

\section{Results and Discussion}

The DAS, ECC and GS taken from the chill end of the casting cast using different chills reveal normal range of structural variations and are discussed in the following sections.

\subsection{Effect of Cooling Rate on Solidification of Chilled Cast Iron}

Solidification of cast iron begins with the crystallization of primary graphite. The primary graphite develops as straight graphite flakes which are totally surrounded by the liquid. The composition of the remaining liquid shifts toward the eutectic where the liquid is believed to solidify in a manner similar to that of the eutectic although the primary graphite may influence the size of the eutectic cell and the distribution of the eutectic graphite. Solidification over a temperature range is the primary requirement for dendrite growth. Primary austenite dendrites readily grow from the liquidus down to the eutectic temperature. Growth of dendrites may also continue concurrently with the eutectic as the temperature decreases through the eutectic range of the solidus. Thus, undercooling may lead to higher dendrite interaction, which was in the case of cast iron cast using different chills [36]. When cast iron containing a certain amount of carbon is cooled slowly from the melt, large flake graphite appears. When cooling is more rapid, the graphite structure will be fine and under cooled graphite or white cast iron may be present depending on the cooling rate. The structure of the graphite is not only influenced by the cooling rate but also by the carbon content. During solidification of cryo chilled and water cooled chilled cast iron, the influence of very high cooling rate influences undercooling of the melt to a lower temperature. This increases the number of effective nuclei for solidification relative to the growth rate, the latter being restricted by the rate at which the latent heat of crystallization can be dissipated. The refining effect of enhanced cooling rate applies both to the primary grain size and to the substructure, although in the latter case, the effect is on the growth process rather than on nucleation. Conversely slow cooling in the case of non metallic chilled 
and sand cast iron favours the growth from a few solidification nuclei and produces coarse grain structures.

Microscopic observation of the samples reveal that, the solidification of metallic and non metallic chilled cast iron will start on a low number of nuclei as compared to the water cooled and sub zero chilled cast iron which reflected in large number of nuclei resulting in high eutectic cell count. Since the growth conditions in the liquid are favourable, these nuclei will start growing as soon as the temperature drops below the equilibrium temperature in case of metallic chilled hypo-eutectic cast iron and with maximum under-cooling in case of water cooled and sub zero chilled cast iron. A mushy type of under cooled graphite which is present apparently reverts to D-type during solidification if cooling is fast. When cooling is slow, the mushy under cooled graphite will be converted into flake graphite even at the beginning of the eutectic reaction. Past research [12] [13] [14] [15] have also showed that, addition of small amount of Si to pure iron containing $3 \% \mathrm{C}$ changed the graphite from a mushy type to flake form. In the present investigation this may be attributing to the fact that addition of $\mathrm{Si}$ ( $2.4 \%$ with ferrosilicon as inoculant) has raised the carbon equivalent, thus increasing the amount of primary austenite dendrites. Therefore in the present research cast iron containing appreciable amount of Si, ledeburite has decomposed to graphite during solidification particularly when iron is forcibly solidified to white cast iron by a severe chilling action.

\subsection{Effect of Cooling Rate on Austenite Dendrite and Its Size}

Primary austenite dendrite was observed under the microscope for all the chilled hypo-eutectic cast irons developed. It was observed that lot of variations in pattern occurring as a result of differences in rate of cooling. For each specimen the structure of the dendrites was analyzed by measuring the dendrite arm spacing and observing the average dendrite length, dendrite interaction and directionality. Marked changes were also produced in graphite morphology by varying the rate of cooling using different type of chills. Primary austenite dendrites would be expected to develop within each of the castings produced in such a manner that their solidification is predicted by the rate of under cooling. For the hypo-eutectic cast iron composition selected in the present investigation and due to cooling provided during solidification, it is believed that the formation of dendrites are prior to nucleation and growth of the eutectic. The eutectic then completes solidification by filling the areas surrounding the dendrites. The resulting structures of transformed primary austenite dendrites traverse a number of eutectic cells which contain both graphite and transformed eutectic austenite. According to some investigations [37], primary austenite dendrites form in hypo-eutectic gray irons only in the localized areas of carbon depletion near the primary graphite phase which presumably solidifies first. But in the present investigation it was observed that, formation of primary dendrites in chilled cast iron prior to the solidification of graphite can be explained by the relatively fast rates of cooling and the under cooling needed for graphite nucleation. The above 
statement is in consistent with the arguments made by Ruff and Wallace [38].

In addition, dendrite interaction which is a visual estimate of the percentage area of dendrites intersecting in a field of view was varied in the specimens tested. The largest degree of dendrite interaction was observed in cast irons chilled using higher cooling rates. The difference in dendrite length, randomness and associated graphite and matrix structure have been related and found that, faster cooling produces fine dendrites. Other factors such as inoculation, alloy content, prior melt history and carbon equivalent may also affect the dendrite morphology, but in the present investigation major factor affecting dendrite morphology is the cooling rate induced during solidification. Finally it is observed that the distribution of the primary austenite dendrites formed in the chilled cast iron cast using different chills follow the solidification behaviour which is different from others. It is found from the present research that decrement in DAS with increased cooling rate explains the fact that there is insufficient time available for diffusion of solute and also on the eutectic composition. It is also observed that the spacing of the arms is controlled by diffusion as well as heat transfer during solidification. The spacing is actually determined by the characteristic thickness of the diffusion zone around a growing dendrite.

\subsection{Effect of Cooling Rate on Microstructure}

The microstructure taken from the chill end reveal the normal range of structural variations in cast irons, viz. varying from ledeburite at the chill end in the case of cryo-cooled and water cooled chills to the random flake graphite in the case of non metallic chilled and sand cast irons. However, the transition from one structure to another was observed to be more gradual than normally obtained in the structures of cast irons solidified multi-directionally in a sand mould at room temperature. The results obtained suggest that some types of graphite in the structure form more likely as a result of the decomposition of carbides during and after the solidification process. Under the range of solidification conditions examined, the microscopic evidence suggests that the austenitic phase is first nucleated by heterogeneous nucleation. The carbide phase appears to be more likely nucleated by the austenite phase, rather than heterogeneously. The metallographic observation of the difference in the distribution of graphite which is also linked with the differences in its shape and size depends on the growth mechanism due to chilling. In the present investigation the effect of $\mathrm{Si}$ is twofold: firstly it minimizes D-type graphite as well as the carbide formation and secondly it promotes paralytic matrix which is desired. All the structural changes observed are due to the mould temperature (chilling) and could be readily accounted for in terms of the initial as well as subsequent solidification or growth under-cooling temperature.

The specimens of chilled cast iron cast using different chills are dictated by the structure of ledeburite, pearlite, cementite and ferrite are as shown in Figures 2-6. Severe chilling at the beginning of the eutectic reaction leads to fine supersaturated austenite in the form of willow leafs are evident in the primary austenite 


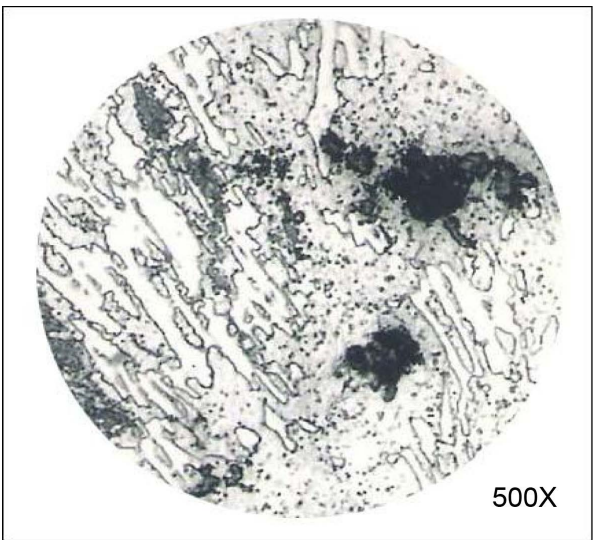

Figure 2. Subzero chilled cast iron (etched) showing matrix structure (ledeburite matrix structure).

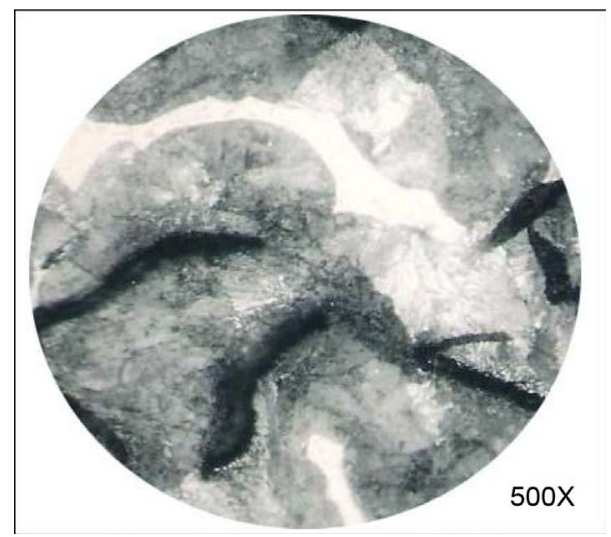

Figure 3. Water cool chilled cast iron (etched) showing matrix structure (few ledeburite with cementite).

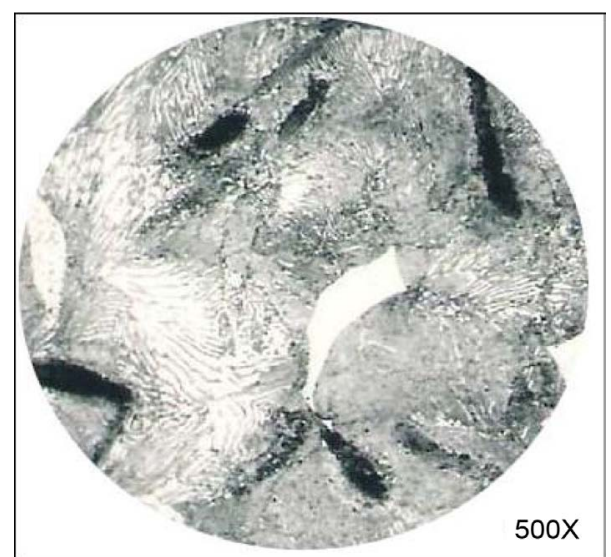

Figure 4. Steel (metallic) chilled cast iron (etched) showing matrix structure (cementite in fine pearlitic matrix).

which is contained in ledeburite (Figure 2). It was observed that due to the change in the mode of solidification, the formation of vermicular/compacted 


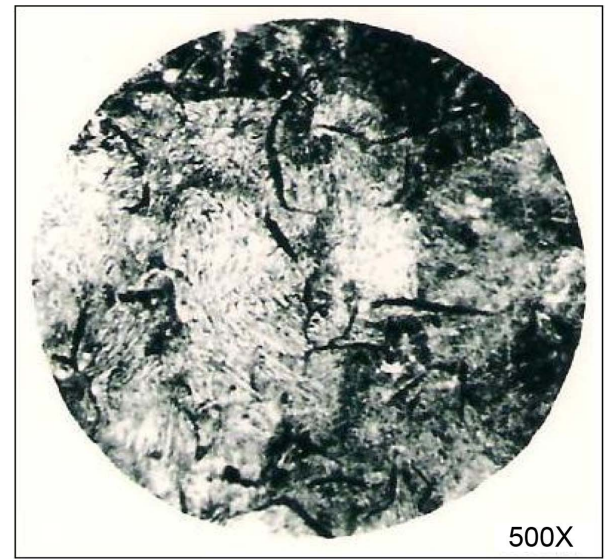

Figure 5. Graphite (nonmetallic) chilled cast iron (etched) showing matrix structure (few cementite in coarse pearlitic matrix).

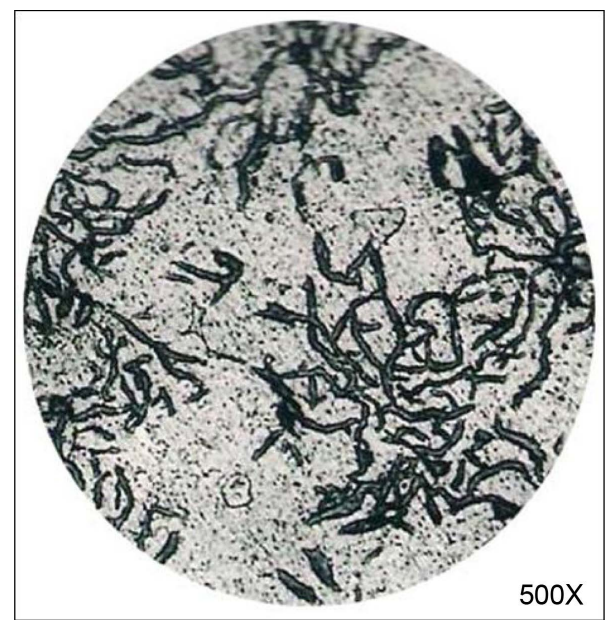

Figure 6. Sand cast iron (unchilled) (etched) showing matrix structure (graphite in ferritic matrix).

graphite as indicated in Figure 7 and Figure 8 (water cooled and metallic chilled cat iron) has shown that a continuously dropping temperature during the bulk or eutectic arrest is essential for the formation of few ledeburite, fine cementite in pearlite matrix (Figure 3 and Figure 4). Thus the eutectic arrest has been identified with the formation of fine cementite in pearlitic matrix. Figure 5 shows non metallic (graphite) chilled cast iron showing ferrite and few cementite in coarse pearlitic matrix. Figure 6 shows sand cast specimen (un-chilled) indicating coarse graphite in ferritic matrix. Finally it can be seen that in the case of cryo and water chilled cast iron the micro-constituents are ledeburite (white patch as in Figure 2 and Figure 3), pearlite (lamellae like pattern, Figure 4 and Figure 5) and cementite (white wavy like pattern, Figure 4 and Figure 5), whereas in the case of metallic and non metallic chilled cast iron, the structure was cementite and ferrite in pearlitic matrix and in the case of sand cast iron it has graphite in ferritic matrix (Figure 6). 


\subsection{Effect of Cooling Rate on Pearlite Content}

Also, if the results shown in Tables 2-4 are compared with one another, it can be seen that there exists an inverse relationship between distance from the chill with pearlite content, ECC and GS and straight forward relationship between distance from the chill and DAS along the length of the casting for the various specimens cast. It is noteworthy that specimens A contain maximum ledeburite and $\mathrm{B}$ contain little ledeburite with maximum cementite in pearlite matrix

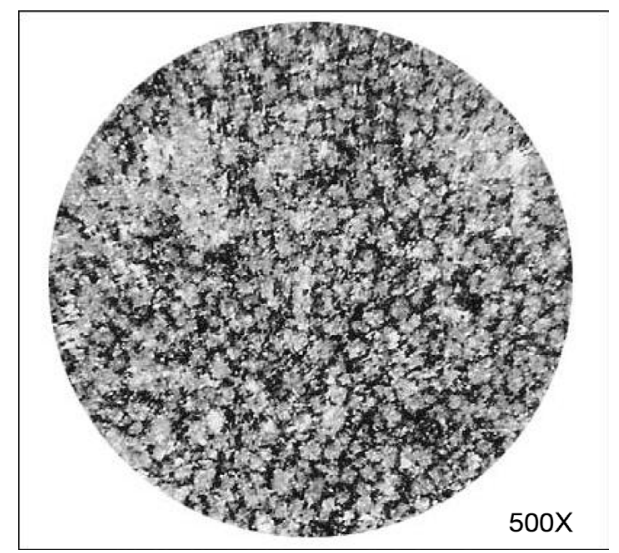

Figure 7. ECC of water cool chilled cast iron.

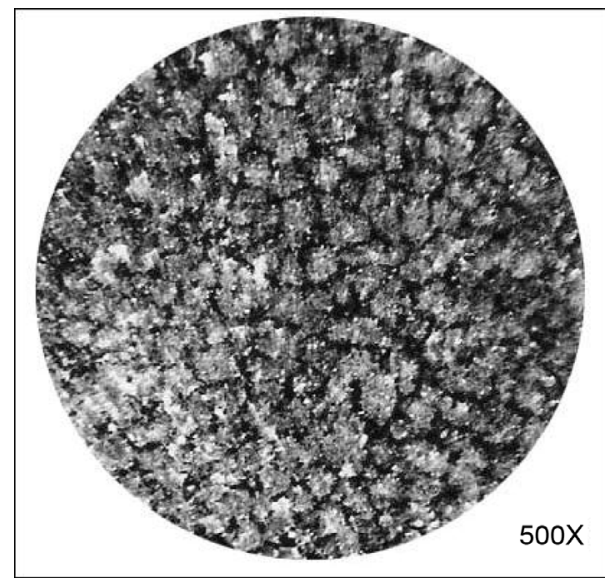

Figure 8. ECC of metal (cu)chilled cast iron.

Table 2. Pearlite content of various chilled cast iron along the length of casting.

\begin{tabular}{cccccc}
\hline \multirow{2}{*}{$\begin{array}{c}\text { Specimen location } \\
\text { Distance from chill end (mm) }\end{array}$} & \multicolumn{5}{c}{ Pearlite content (vol.\%) (at 500×) } \\
\cline { 2 - 6 } 30 (chill end) & Specimen A & Specimen B & Specimen C & Specimen D & Specimen E \\
70 & 59 & 68 & 51 & 24 & 08 \\
105 & 57 & 62 & 50 & 24 & 08 \\
145 & 42 & 60 & 49 & 22 & 08 \\
180 & 34 & 40 & 48 & 22 & 10 \\
225 (riser end) & 30 & 34 & 49 & 20 & 10 \\
\hline
\end{tabular}

(Note: The remaining micro-constituents are cementite, ledeburite and ferrite). 
Table 3. Eutectic cell count of various chilled cast iron along the length of casting.

\begin{tabular}{|c|c|c|c|c|c|}
\hline \multirow{2}{*}{$\begin{array}{c}\text { Specimen location } \\
\text { Distance from chill end }(\mathrm{mm})\end{array}$} & \multicolumn{5}{|c|}{ No. of Eutectic cells $/ \mathrm{cm}^{2}$ ( $50 \times$ magnification $)$} \\
\hline & Specimen A & Specimen B & Specimen C & Specimen D & Specimen E \\
\hline 30 (chill end) & 190 & 168 & 142 & 84 & 72 \\
\hline 70 & 174 & 150 & 130 & 78 & 74 \\
\hline 105 & 106 & 108 & 104 & 76 & 74 \\
\hline 145 & 106 & 96 & 96 & 76 & 74 \\
\hline 180 & 96 & 96 & 90 & 74 & 74 \\
\hline 225 (riser end) & 70 & 70 & 72 & 74 & 74 \\
\hline
\end{tabular}

Table 4. Grain size of various chilled cast iron along the length of casting.

\begin{tabular}{cccccc}
\hline \multirow{2}{*}{$\begin{array}{c}\text { Specimen location } \\
\text { Distance from chill end (mm) }\end{array}$} & \multicolumn{5}{c}{ No. of grains/inch $^{2}$ (at 500× $)$} \\
\cline { 2 - 6 } & Specimen A & Specimen B & Specimen C & Specimen D & Specimen E \\
\hline 30 (chill end) & 126 & 124 & 119 & 72 & 32 \\
70 & 64 & 64 & 58 & 38 & 30 \\
105 & 64 & 32 & 30 & 32 & 30 \\
45 & 32 & 32 & 32 & 30 & 30 \\
180 & 32 & 32 & 32 & 30 & 32 \\
225 (riser end) & 44 & 48 & 30 & 30 & 32 \\
\hline
\end{tabular}

whereas specimen $C$ contain few cementite in pearlite matrix (Figures 2-6). Past research also showed that addition of small amount of $\mathrm{Mn}$ promotes the matrix in cast iron that contain both ferrite and pearlite [39]. In the present research it is observed that at the eutectoid temperature, pearlite is nucleated by cementite and it appears on the boundaries of flake graphite and austenite. This cementite which precipitates on austenite boundaries decomposes to graphite and austenite on cooling. Therefore both cementite and pearlite are seen (Figure 3 and Figure 4) in cast iron containing Mn. Therefore the flake graphite precipitates on cooling, cementite crystallizes out on the graphite at the eutectoid temperature and is followed by pearlite formation.

Table 2 shows pearlite content of the specimen A, B, C, D and E along the length of the casting. It can be seen from the Table 3 that in the case of cryo and water chilled cast iron the micro-constituents are ledeburite (white patch as in Figure 2), pearlite (lamellae like pattern, Figure 3 and Figure 4) and cementite (white weavy like pattern, Figures 3-5), whereas in the case of metallic and non metallic chilled cast iron, the structure was cementite and ferrite in pearlitic matrix and in the case of sand cast iron it has graphite in ferritic matrix.

\subsection{Effect of Cooling Rate on Eutectic Cell Count (ECC)}

Solidification of hypoeutectic cast iron begins with the crystallization of primary graphite [40]. The primary graphite develops as straight graphite plates with some branching growing while totally surrounded by liquid. The composition of the remaining liquid shifts towards the eutectic where the liquid is believed to 
solidify in a manner similar to that of a eutectic cell although the primary graphite may influence the size of the eutectic cell and the distribution of the eutectic graphite. Since it is generally accepted that the eutectic cell count is an indication of the number of nuclei on which solidification has taken place [41]. Present research was designed in order to compare the eutectic cell counts of water-cooled, liquid-nitrogen-cooled, metallic and non metallic chilled cast iron with ordinary sand-cast iron. Some typical photomicrographs of eutectic cells (near the chill end) for liquid-nitrogen-cooled, water cooled, metallic, non metallic chilled and sand cast iron are shown in Figures 7-11. It can be seen from figures that as eutectic cell count increases until the cells become compacted and the difference between the eutectic cell counts for water-cooled and liquid-nitrogen-cooled chilled cast iron is small whereas that between the eutectic cell counts for chilled cast iron and sand-cast iron is very large. Typical values are $190 \mathrm{cells} / \mathrm{cm}^{2}$ for liquid-nitrogen-cooled (near the chill end), $168 \mathrm{cells} / \mathrm{cm}^{2}$ for water-cooled (near the chill end) and 72 cells $/ \mathrm{cm}^{2}$ for sand-cast iron without chill. Table 3 shows ECC for specimen A, B, C, D and E along the length of the casting.

It is to be noticed here that the number of nuclei available for solidification of cryo-cooled, water cooled and metallic chilled cast iron are higher than the

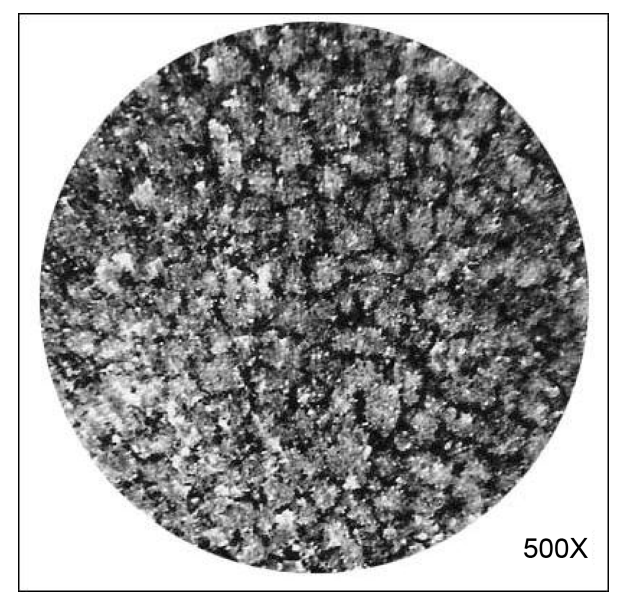

Figure 9. ECC of subzero chilled cast iron.

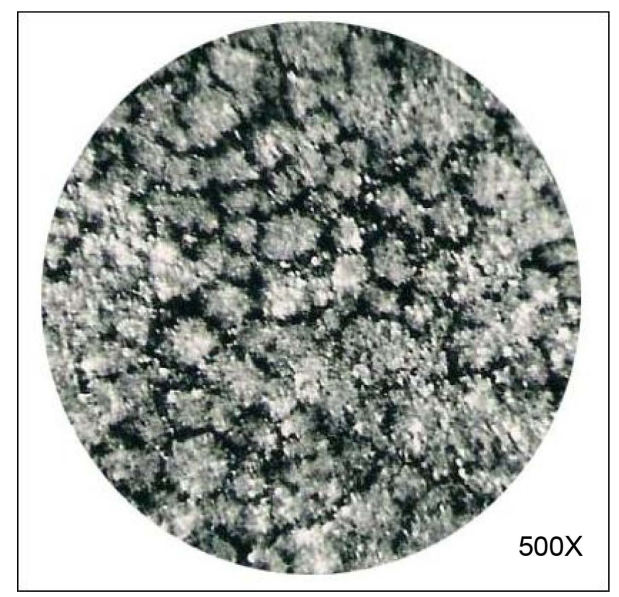

Figure 10. ECC of nonmetal chilled cast iron. 


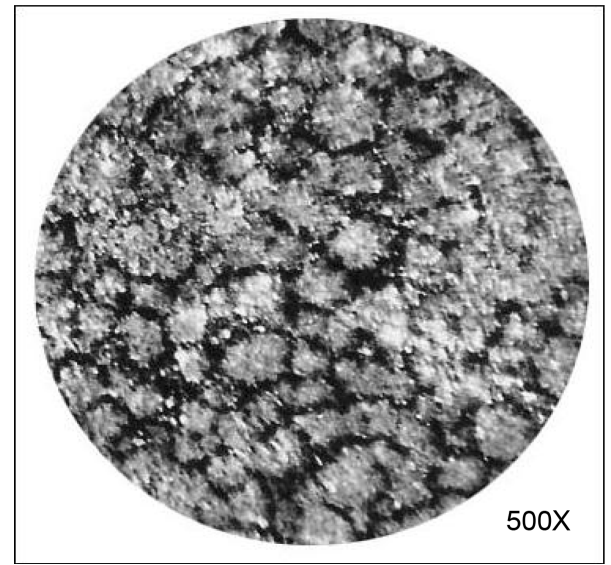

Figure 11. ECC of sand cast specimen.

number of nuclei available for solidification of non metallic chilled and sand cast iron. This is due to the under-cooling effect caused by chilling. However, there are significantly fewer nuclei for solidification in the case of sand-cast iron without a chill. Solidification of flake graphite iron resulting from sand casting without a chill starts from a small number of nuclei as compared with chilled cast iron, a phenomenon indicated by eutectic cell count. Since the growth condition in the liquid is favourable, these nuclei start growing as soon as temperature below the equilibrium temperature in case of sand cast iron. Perhaps the most important fact to recognize regarding cell structure is that it develops after the precipitation of austenite dendrite structure which solidifies first. The dendritic structure hosts the cells and therefore can have a major effect on cell nucleation and growth. The solidification of flake graphite iron resulting from sand casting without a chill starts from a small number of nuclei as compared with chilled (water-cooled and liquid-nitrogen-cooled) cast iron, a phenomenon indicated by eutectic cell count. Since the growth condition in the liquid are favourable, these nuclei start growing as soon as temperature below the equilibrium temperature in case of sand cast iron and with maximum under cooling in the cases of chilled cast iron, whether water-cooled or liquid-nitrogen-cooled. The structural parameters studied include eutectic cell count, cell size, distribution and the cell rating. Eutectic cell count observations under the microscope showed that the nodule count of chilled cast iron lies between a large range of 190 cells $/ \mathrm{cm}^{2}$ (for sub zero chilled) and $72 \mathrm{cells} / \mathrm{cm}^{2}$ (for sand cast, un chilled) the larger nodule count being generally associated with very high cooling rates or chill effectiveness and vice versa. It appears that the nodule counts are directly proportional to the bulk arrest temperature. This shows that nodule count also finds an excellent correlation with the chilling rate.

\subsection{Effect of Cooling Rate on Grain Size}

The operating mechanism according to the current solidification method is the factor that affects the growth kinetics during freezing i.e., as the speed of cooling lowers the freezing temperature more nuclei grows and thus balancing the diffu- 
sion and equating the heat loss to the chill with the gain from the heat of fusion liberated. It was observed that the changes from one recognized graphite form to another occur by a gradual change in the graphite and cell morphology which would be the characteristic and unique nucleation event required for each graphite form. This graphite morphology is perhaps one of the factors in determining the microstructure of cast iron and cell morphology for the grain size of cast iron. Grain size for cryo-chilled specimen is maximum near the chill end and decreases towards the riser end. But near the riser end there is slight increase in the grain size and this is due to the riser effect where the casting is dense. The fine grain size in the case of chilled cast iron results in the soundness of the casting (chilling effect) and hence its high strength.

Table 4 shows the results of microscopic studies on grain size. It can be seen that the grains in the case of sub zero chilled cast iron were fine but the grains were very coarse in the case of graphite (non metallic) chilled cast iron and sand-cast iron, cast without a chill. In chilled cast iron, the experimental data show that the cell morphology is the principal factor in determining the grain size rather than the graphite morphology an observation supported by H. Fedrikson and M. Hillert [42].

\section{Conclusions}

Analysis of data on chilled cast iron using various types of chills showed that the cooling rate had a marked effect on solidification, DAS, microstructure, ECC and GS. It was found from the present research that:

Austenite dendrite interactions were shown to be a major factor in determining the microstructure, in which higher dendrite reaction leads to changes in DAS, ECC and GS. It is observed that, the number of eutectic cells is an index of graphite nucleation and the effect of these on structure, since the eutectic cells are developed on the graphite nuclei during solidification.

The microstructure taken from the longitudinal samples at various distances from the chill reveals the normal range of structural variations in cast irons, viz. varying from ledeburite at the chill end in the case of cryo-cooled and water cooled chills to ferrite and graphite in the case of nonmetallic chilled and sand cast irons. The results obtained suggest that some types of graphite in the structure form more likely as a result of the decomposition of carbides during and after the solidification process. Under the range of solidification conditions examined, the microscopic evidence suggests that the austenitic phase is first nucleated by heterogeneous nucleation. Then the carbide phase appears to be more likely nucleated by the austenite phase, rather than heterogeneously.

It has been found that higher cooling rate produces finer dendrite arm spacing and conversely the DAS increases as the cooling rate decreases because there is sufficient time available for diffusion of the solute. Therefore the decrement in DAS with increased cooling rate explains the fact that there is insufficient time available for diffusion of solute and also on the eutectic composition. Hence, it is concluded that diffusion controls the DAS. 
It observed that eutectic cell count increased for water-cooled and liquidnitrogen-cooled chilled cast iron due to the under-cooling effect caused by chilling. On the other hand for nonmetallic chilled and sand cast iron, the cell count is very small because there are significantly fewer nuclei available for solidification. Thus it is concluded that the number of nuclei available for solidification of cryo-cooled, water cooled and metallic chilled cast is higher than the number of nuclei available for solidification of nonmetallic chilled and sand cast iron.

Grain sizes in the case of chilled cast iron were fine but the grains were very coarse in the case of graphite (non metallic) chilled cast iron and sand-cast iron without a chill. In chilled cast iron, the experimental data show that the cell morphology is the principal factor in determining the grain size.

\section{References}

[1] Hemanth, J. (2001) Solidification Behavior of Water Cool and Sub Zero Chilled Cast Iron on Mechanical Behaviour. Journal of Materials Engineering and Performance, 10, 28-39. https://doi.org/10.1361/105994901770345231

[2] Hemanth, J. (2010) Microstructure, Mechanical Properties and Wear Behavior of Metallic, Non Metallic and Deep Cryogenically Chilled ASTM 216 WCB Steel. Journal of Alloys and Compounds, 506, 645-652. https://doi.org/10.1016/j.jallcom.2010.07.036

[3] Hemanth, J. (2001) Effect of Sub Zero Chilling (Cryogenic) with Water Cool Chilling on Solidification and Mechanical Behaviour of Cast Iron. Materials Science and Engineering A, 318, 277-286. https://doi.org/10.1016/S0921-5093(01)01327-2

[4] Hemanth, J. (2010) Effect of Chilling on the Mechanical Properties and Wear Resistance of Cr Added ASTM A216 Grade WCB Steel. International Journal of Materials Science, 5, 131-137.

[5] Hemanth, J. (1996) Wear Characteristics of Sub Zero Chilled Cast Iron. Wear, 192, 134-140. https://doi.org/10.1016/0043-1648(95)06781-7

[6] Murthy, K.S.S., Seshadri, M.R. and Ramachandran, A. (1965) Plate-Feeder Design for Al Alloy Castings. Trans AFS, 73, 502-510.

[7] Murthy, K.S.S., Seshadri, M.R. and Ramachandran, A. (1967) Influence of Chills on Solidification Behavior of Long Freezing Range Alloys. 34th International Foundry Congress, Paris, 56-63.

[8] Seshan, S., Seshadri, M.R. and Ramachandran, A. (1968) Action of Chills on Soundness of Al-4.5\%Cu Alloy Castings. The British Foundryman, 61, 3-12.

[9] Hemanth, J. (2005) Tribological Behavior of Cryogenically Treated Al-12\%Si Alloy/B4C Composites. Wear, 258, 1732-1739. https://doi.org/10.1016/j.wear.2004.12.009

[10] Hemanth, J. (2011) Development and Wear Behavior of Al/Al2SiO5/C Chilled Hybrid Metal Matrix Composites by Both Experimental and Finite Element Method. SAE International, PA, USA, Paper No. 2011-01-0223.

[11] Hemanth, J. (2003) Effect of High Rate Heat Transfer during Casting on Strength, Hardness and Wear Behaviour of Al/Quartz MMCs. Proceedings of the Institution of Mechanical Engineers Part B, 217, 651-659. https://doi.org/10.1243/095440503322011371

[12] Dawson, J.V. and Oldfield, W. (1960) Effect of Ferro Silicon Oneutectic Cell Count. 
BCIRA Journal, 8, 221-234.

[13] Wallace, J.W. (1975) Effects of Minor Elements in the Structure of Cast Irons. Trans AFS, 88, 363-369

[14] Church, N. (1966) Control of Cast Grain Size of Steel Castings, Effect of Grain Refinement on Properties. Trans AFS, 74, 113-120.

[15] Bhur, R.K. (1986) Vermicular Graphite Formation in Heavy Section Nodular Cast Iron. Modern Castings, 54, 497-502.

[16] Loper, C.R. and Heine, R.W. (1962) Graphite Formation during Solidification of Cast Iron. Trans AFS, 70, 583-589.

[17] Michael, A.B. and Bever, M.B. (1950) Graphite Morphology in Ductile Irons. Trans AIME, 188, 47-55.

[18] Tiller, W.A. (1964) Isothermal Solidification of Fe-C and Fe-C-Sialloys. ASM Seminar, Research on Cast Iron, Detroit, No. 12, 34-40.

[19] Ruff, G.F. and Wallace, J.F. (1976) Control of Graphite Structure and Its Effects Mechanical Properties of Gray Iron. Trans AFS, 84, 705-711.

[20] Hughes, I.C.H. (1952) Some Effects of Mg on the Formation of Graphite in a Solidifying Cast Iron. Foundry Trade Journal, 92, 417-424.

[21] Hilbert, H. (1964) Some Theoretical Considerations in Nucleation and Growth during Solidification of Graphite and White Cast Irons. ASM Seminar, Research on Cast Iron, Detroit, No. 23, 56-63.

[22] Seshan, S. and Ramachandran, A. (1968) Action of Chills on Soundness of Al4.5\%Cu Alloy Castings. The British Foundryman, 61, 339-347.

[23] Reddy, G.P. and Pal, P.K. (1976) Influence of Chills on Al-4.5\%Cu Alloy Casting Soundness. The British Foundryman, 69, 265-272.

[24] Hemanth, J. and Seah, K.H.W. (1995) Fracture Toughness of Sub Zero Chilled Cast Iron. Journal of Materials Science, 30, 4986-4993. https://doi.org/10.1007/BF01154513

[25] Itaka, I. (1951) Theory of Globular Graphite Formation in Cast Iron. Foundry Trade Journal, 91, 498-504.

[26] Fedriksson, H. and Hillert, M. (1971) Direct and Indirect Formation of Graphite in High Alloyed Cast Iron. The British Foundryman, 43, 54-59.

[27] Bishop, H.F. (1951) Solidification of Cast Irons. Trans AFS, 59, 435-441.

[28] Berry, J.T. (1970) Vermicular Graphite Formation in Heavy Section Nodular Cast Iron. Trans AFS, 78, 421-431.

[29] Ruff, G.F. and Wallace, J.F. (1977) Effect of Solidification Structures on the Tensile Properties of Gray Iron. Trans AFS, 85, 179-184.

[30] Sun, G.X. and Loper, C.R. (1983) Graphite Flotation in Cast Iron. Trans AFS, 91, 841-848.

[31] Wallace, J.W. (1975) Effects of Minor Elements in the Structure of Cast Irons. Trans AFS, 88, 363-369.

[32] Ruddle, R.W. (1950) Solidification of Castings. Institute of Metals, London.

[33] Igarshi, I., Ohira, G. and Ikawa, G. (1958) Under Cooled Graphite in Cast Irons. Trans AFS, 60, 561-572.

[34] Alexander, B.H. and Rhines, M.B. (1950) Secondary Dendrite Arm Spacing in Ferrous Alloys. Trans AIME, 188, 1267-1276.

[35] Glover, D. and Bates, C.E. (1982) The Relationship among Carbon Equivalent, Microstructure and Solidification Characteristics and Their Effect on Strength and 
Chill in Gray Cast Iron. Trans AFS, 90, 745-755.

[36] Radzikowska, J.M. (2010) Graphite Flotation in White Cast Iron. Foundry Research Institute, Krakow, 34-45.

[37] Zeytin, H., Kubiley, K. and Aydin, H. (2009) The Relationship among Carbon Equivalent, Microstructure and Solidification Characteristics and Their Effect on Strength and Chill in Gray Cast Iron. Journal of Iron and Steel Research, International, 6, 32-36. https://doi.org/10.1016/S1006-706X(09)60040-6

[38] Ruff, G.F. and Wallace, J.F. (1977) Effect of Solidification Structures on the Tensile Properties of Gray Iron. Trans AFS, 85, 167-174.

[39] Shaha, S. and Dyuti, S. (2010) Effects of Minor Elements in the Structure of Irons. Journal of Applied Sciences, 10, 1196-1199.

[40] Suzuki, K. and Kayama, N. (1982) Graphite Nucleation out of Residual Graphite Particles in Molten Cast Iron and Its Chill Decreasing Effect. Trans AFS, 90, 423-430.

[41] Krawczyk, J. and Pacyna, J. (2009) Theory of Globular Graphite Formation in Cast Iron. Metal, 5, 19-21.

[42] Fedriksson, H. and Hillert, M. (1971) Direct and Indirect Formation of Graphite in High Alloyed Cast Iron. The British Foundryman, 43, 54-61.

Submit or recommend next manuscript to SCIRP and we will provide best service for you:

Accepting pre-submission inquiries through Email, Facebook, LinkedIn, Twitter, etc. A wide selection of journals (inclusive of 9 subjects, more than 200 journals)

Providing 24-hour high-quality service

User-friendly online submission system

Fair and swift peer-review system

Efficient typesetting and proofreading procedure

Display of the result of downloads and visits, as well as the number of cited articles

Maximum dissemination of your research work

Submit your manuscript at: http://papersubmission.scirp.org/

Or contact mnsms@scirp.org 